\title{
EFEKTIVITAS PENDEKATAN KONSTEKTUAL TERINTEGRASI AL- QURAN TERHADAP HASIL BELAJAR SISWA PADA MATERI SISTEM REPRODUKSI MANUSIA
}

\author{
Sofian, Indayana Febriani Tanjung, Rasyidah \\ Universitas Islam Negeri Sumatera Utara, Indonesia \\ Email: Sofianfaqod123@gmail.com
}

\begin{abstract}
Abstrak
Penelitian ini bertujuan untuk mengetahui Efektivitas Pendekatan Konstektual Terintegrasi Al-Quran Terhadap Hasil Belajar Siswa Pada Materi Sistem Reproduksi Manusia Di MA LAB IKIP Al-Wasliyah Medan. Metode yang digunakan dalam penelitian ini merupakan metode penelitian experiment yang pelaksanaannya menggunakan jenis quasi experiment dengan desain nonequivalent control group design. Populasi penelitian terdiri dari 30 siswa yang terbagi menjadi 2 kelas, yaitu kelas XI-1 MA berjumlah 15 siswa dan kelas XI-2 MA berjumlah 15 siswa. Hasil belajar pada kelas kontrol yang menggunakan pendekatan ceramah (konvensional) memperoleh hasil kurang memuaskan. Perhitungan yang dilakukan menggunakan uji $N$-gain yang menunjukkan pada kelas eksperimen sebesar 0,87 (kategori sedang) dan pada kelas kontrol sebesar 0,58 (kategori sedang) dan menggunakan uji $t$ independent sample test yang menunjukkan bahwa $t_{\text {tabel }}<t_{\text {hitung }}(1,69<2,25)$ pada taraf kesalahan 5\%. Selisih persentase kenaikan dari pretest ke posttest juga lebih besar kelas ekperimen dengan $84,4 \%$ dan kelas kontrol dengan 75,4 \%. Jadi sumbangan efektif penggunaan model pembelajaran $C T L$ sebesar $11,8 \%$. Dengan demikian, dapat diputuskan bahwa terdapat perbedaan yang signifikan antara hasil belajar kelas eksperimen yang menggunakan pendekatan konstektual terintegrasi Al-Quran dengan kelas kontrol yang menggunakan pendakatan ceramah (konvensional).
\end{abstract}

Kata Kunci: CTL (Konstektual Teaching and Learning), Sistem Reproduksi, Hasil Belajar.

\section{Abstract}

This study aims to determine the Effectiveness of the Integrated Contextual Approach of the Koran on Student Learning Outcomes on Human Reproductive System Material at MA LAB IKIP Al-Washliyah Medan. The method used in this study is an experiment which is implemented using a quasi-experimental with a nonequivalent control group design. The research population consisted of 30 students who were divided into 2 classes, namely class XI-1 MA with 15 students and class XI-2 MA with 15 students. Learning outcomes in the control class using a lecture approach (conventional) obtained unsatisfactory results. Calculations were carried out using the $N$-gain which showed that in the experimental class it was 0.87 (medium category) and in the control class it was 0.58 (medium category) and used the t-test independent sample test which shows that table < $t_{\text {count }}(1.69<2.25)$ at an error level of $5 \%$. The difference in the percentage 
increase from pretest to posttest was also greater for the experimental class with $84.4 \%$ and the control class with $75.4 \%$. So the effective contribution of using the CTL is $11.8 \%$. Thus, it can be concluded that there is a significant difference between the learning outcomes of the experimental class using an integrated contextual approach to the Qur'an with a control class that uses a lecture (conventional) approach.

Keywords: CTL (Contextual Teaching and Learning), Reproductive System, Learning Outcomes.

Diserahkan: 03-01-2022Ｄiterima: 25-01-2022Ｄiterbitkan: 20-02-2022

\section{Pendahuluan}

Secara ideal, pembelajaran biologi mengembangkan pengetahuan agar dapat mengerti dan mengetahui pembelajaran nilai (kognitif) dan tingkah laku (afektif) dan, menciptakan hasil karya sebagai kreatifitas (psikomotor), hal tersebut merupakan komponen esensial. Dalam pemahaman seperti itu, maka pengembangan nilai dan etika dalam biologi tidak tepat lagi jika hanya diposisikan sebagai komponen krusial atau sebagai kurikulum tersembunyi. Nilai dan etika harus secara eksplisit dijabarkan dan diperkaya dalam setiap topik pembelajaran. Biologi merupakan salah satu bagian ilmu pengetahuan alam yang menekankan pemberian pengetahuan langsung siswa secara alamiah, yaitu pembelajaran yang diarahkan pada ketercapaian keterampilan dalam konteks kehidupan nyata (learning in real life setting). Oleh karena itu untuk meningkatkan nilai hasil belajar dan juga pengalaman siswa terhadap konsep-konsep biologi maka guru perlu memikirkan, merencanakan, dan menerapkan suatu pendekatan pembelajaran yang membuat siswa aktif dan merasa senang dalam belajar biologi.

Berdasarkan observasi di MA LAB IKIP Al-Wasliyah Medan menunujukkan bahawa proses belajar mengajar berjalan secara teoritis. Hal tersebut dapat dilihat dari rata- rata hasil belajar biologi peserta didik yaitu 70,5 dan tidak melampau kriteria ketuntasan minimal yaitu 75 . Ketidaktuntasan hasil belajar siswa dipengaruhi oleh banyak faktor, salah satunya adalah ketidaktepatan penggunaan model pembelajaran yang digunakan guru di kelas. Kenyataan menunjukkan bahwa selama ini kebanyakan guru menggunakan model pembelajaran konvensional dan banyak didominasi oleh guru (Nurhayati abbas, 2017).

Hal demikian terjadi karena pembelajaran yang digunakan tidak melibatkan dunia nyata dan tidak memperhatikan pengalaman siswa. Akibatnya, siswa merasa jenuh, malas dan pasif. Oleh karena itu, perlu ada perubahan dalam proses pembelajaran. Siswa termotivasi jika pembelajaran yang dilakukan mengkaitkan materi dengan kehidupan sehari-hari, sehingga materi yang diterima terkonstruksi oleh siswa dengan sendirinya memutuskan setiap hal untuk kebutuhan belajar.

Mengatasi masalah tersebut, diperlukan adanya sebuah strategi pembelajaran yang lebih memberdayakan siswa, yaitu suatu pendekatan pembelajaran yang mampu meningkatkan hasil belajar siswa. Pendekatan pembelajaran ini salah satunya menekankan bagaimana belajar di sekolah yang dikontekskan ke dalam situasi dunia 
nyata, sehingga hasil belajar dapat diterima dan berguna bagi siswa selama di sekolah atau setelah mereka lulus dari sekolah tersebut (Hamdayama Jumanta, 2014).

Pendekatan pembelajaran tersebut adalah pendekatan pembelajaran yang didasarkan kepada pembelajaran pendekatan konstektual terintegrasi Al- Quran yang diharapkan dapat menciptakan keseimbangan ilmu pengetahuan yang akan diperoleh peserta didik. Pembelajaran bernilai islam dirasa akan menjadi salah satu pilihan sumber belajar yang tepat bagi peserta didik pada masa sekarang ini, dikarenakan akan membantu peserta didik dalam mempelajari materi yang diinginkan dan tentunya materi tersebut akan dikuatkan dengan dalil Al-Qur'an yang berkaitan dengan materi yang dipelajari, sehingga dengan adanya pendekatan CTL terintegrasi Al-Qur'an dalam hal ini, peserta didik akan mendapatkan dua keunggulan, yaitu tetap dapat belajar materi yang diinginkan dengan mudah dan mendapatkan penguatan mengenai materi tersebut secara islami yaitu dengan penguatan integrasi ayat-ayat Al-Qur'an yang berkaitan dengan materi pembelajaran.

Pendekatan kontekstual adalah pengajaran yang memungkinkan para siswa mampu menguatkan, memperluas, dan menerapkan pengetahuan dan keterampilan, akademik mereka dalam berbagai macam tatanan dalam sekolah dan, luar sekolah agar dapat memecahkan masalah-masalah dunia nyata (Elaine B. Johnson, 2018). Pembelajaran ini berawal dari asumsi bahwa anak belajar lebih baik melalui kegiatan belajar sendiri dalam lingkungan yang alamiah. Proses pembelajaran berlangsung alamiah dalam bentuk kegiatan siswa beketja dan mengalami, bukan transfer pengetahuan (Jumanta Hamdayama, 2014). Dengan demikian, siswa dapat mengerti makna belajar, manfaat dan cara mencapai pelajaran agar pembelajaran dapat berguna bagi kehidupan.

Salah satu pokok bahasan yang erat kaitannya dengan kehidupan sehari-hari yaitu sistem reproduksi manusia. Materi sistem reproduksi manusia juga banyak dijelaskan dalam Al-Quran dalam proses penciptaannya dan hakikatnya diciptakannya manusia oleh Allah SWT. Oleh karena itu, perlu adanya pengintegrasian materi sistem reproduksi manusia dengan konsep islam, agar peserta didik dapat menumbuhkan nuansa islami dalam pembelajaran Biologi, khususnya pada materi sistem reproduksi manusia (Sholeh, 2016).

Sistem reproduksi manusia adalah sistem yang melibatkan fartilasasi internal dengan hubungan seksual. Dalam proses ini, laki- laki memasukkan penis kedalam vagina dan berejakulasi semen yang mengandung sperma. Allah berfirman dalam AlQur'an surat Al-Mu'minun ayat 12-14 yang berbunyi:

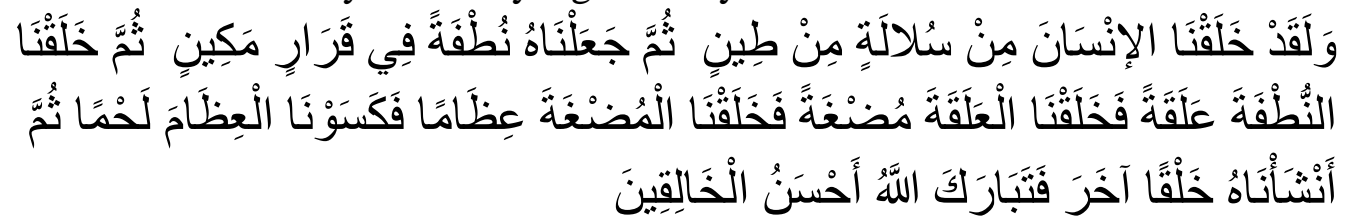

"Dan Sesungguhnya kami Telah menciptakan manusia dari suatu saripati (berasal) dari tanah Kemudian kami jadikan saripati itu air mani (yang disimpan) dalam tempat yang kokoh (rahim) Kemudian air mani itu kami jadikan segumpal darah, 
lalu segumpal darah itu kami jadikan segumpal daging, dan segumpal daging itu kami jadikan tulang belulang, lalu tulang belulang itu kami Bungkus dengan daging. Kemudian kami jadikan dia makhluk yang (berbentuk) lain. Maka Maha sucilah Allah, Pencipta yang paling baik.

Proses penciptaan manusia diawali dari saripati makanan yang dikonsumsi yang bersumber dari tanah kemudian dijadikan nutfah yang bercampur (nutfah amsyāj) yang disimpan dalam tempat yang kokoh yakni rahim yang memiliki struktur yang mampu melindungi janin. Kemudian nutfah yang bercampur itu dijadikan segumpal darah yang mirip kecebong yang menempel pada dinding rahim, lalu segumpal darah itu dijadikan segumpal daging yang ukurannya kecil sehingga bisa dikunyah, dan segumpal daging itu dijadikan tulang belulang lengkap dengan urat-urat syarafnya, lalu tulang belulang itu dibungkus dengan daging, kemudian disempurnakan penciptaannya dengan ditiupkan roh ke dalamnya sehingga menjadi makhluk yang berbentuk lain yakni manusia yang memiliki karakterkarakter istimewa dibanding makhluk yang lain. Maka Maha sucilah Allah, Pencipta yang paling baik dari para pencipta yang lain.

Menurut Ahmad Musthafa Al-Maragi mengatakan al-Khalaq (penciptaan) dalam firman Allah: Inna Khalaqnakum min turabin, kadang merujuk kepada penciptaan Adam saja, dan kadang berarti bahwa air mani pada setiap laki-laki dan wanita adalah hasil dari proses makan yang dengan itu manusia atau tubuh makan. Proses makan ini berasal dari tanah. Nutfah, adalah air mani laki-laki dan sel telur wanita. Apabila terjadi perkawinan antara air mani dan telur itu serta telur mulai terbagi maka mulailah perkembangan darah beku, yaitu sel-sel hidup kepadanya telur terbagi setelah perkawinannya. Dinamakan perkembangan ini dengan 'alaqah (darah beku) karena adanya keserupaan yang besar antara darah lintah air (Ahmad Musthafa Al-maragi, 2006).

Masa perkembangan darah beku dalam kehidupan janin mencapai empat minggu, kemudian berkembang menjadi mudghah (sepotong daging) karena serupa benar dengan sepotong daging yang bisa dimamah dan masa perkembangannya mencapai tiga sampai sepuluh minggu. Sesudah itu, mulai tampak sel-sel tulang, lalu daging, yakni otot-otot yang membungkus tulang.

Firman-Nya: al-qararal-makin berarti tempat menetap yang kokoh yakni, rahim. Orang yang mempelajari anatomi rahim dan tempatnya itu mempunyai dinding yang lebar dan dalam, kemudian melihat jaringan yang lebar dan jaringan yang bundar, gelembung kencing dan otot yang lurus, semuanya memelihara keimbangan dan menguatkan rahim serta menjaganya dari miring atau jatuh, lalu memanjang bersamanya apabila rahim naik mendek secara alami setelah bersalin, demikan pula orang yang mempelajari bagaimana kolam membentuk tulangnya, niscaya dia akan mengetahui dengan jelas kebenarannya. 


\section{Metode Penelitian}

Penelitian yang saya lakukan ini merupakan penelitian kuantitatif. Penelitian ini saya lakukan di Kelas XI MA LAB IKIP Al - Washliyah Medan. Penelitian ini dilakukan untuk mengetahui efektivitas pendekatan konstektual disertai terhadap hasil belajar biologi kelas XI MA LAB IKIP Al - Washliyah Medan pada materi sistem reproduksi manusia. Untuk pengambilan datanya saya menggunakan tes hasil belajar (Purwanto, 2018). Tes hasil belajar yang digunakan ada dua yaitu pretest dan posttest. Pretest bertujuan untuk mengetahui tingkat pemahaman siswa sebelum kegiatan pengajaran diberikan, sedangkan posttest bertujuan untuk mengetahui tingkat pemahaman siswa setelah kegiatan pengajaran diberikan. Data diperoleh dari 30 peserta didik, kelas XI- 1 MA terdiri dari 15 siswa sebagai kelas eksperimen dan XI-2 MA terdiri dari 15 siswa sebagai kelas kontrol.

Pembelajaran yang digunakan pada kelompok eksperimen adalah pembelajaran dengan menggunakan pendekatan Kontekstual (CTL) terintegrasi Al-quran, sedangkan untuk kelompok kontrol adalah pembelajaran dengan menggunakan pendekatan Konvensional. Kelompok eksperimen maupun kelompok kontrol sebelum melakukan pembelajaran, diberikan pretest terlebih dahulu untuk mengetahui bahwa kedua kelompok tersebut berangkat dari kondisi yang sama atau tidak. Setelah kedua kelompok diketahui berangkat dari kondisi yang sama, kemudian kelompok eksperimen di beri perlakuan dengan menggunakan model pembelajaran kontekstual. Selanjutnya kedua kelompok diberi posttest untuk mengukur perbedaan prestasi belajarnya. Apabila data sudah terkumpul maka selanjutnya dianalisis menggunakan uji normalitas, uji homogenitas dan uji hipotesis mengunakan aplikasi Anates dan microsoft exsel.

\section{Hasil Dan Pembahasan}

Pembelajaran dengan model kontekstual terintegrasi Al-Quran menuntut siswa untuk aktif dalam proses pembelajaran. Aktivitas pembelajaran di kelas terjadi interaksi banyak arah. Karena kodrat manusia sebagai mahkluk sosial yang peka terhadap keadaan sekitar, hubungan yang menarik serta harmonis terjadi antara guru dengan siswa maupun siswa dengan siswa. Proses pembelajaran berlangsung secara alami dan komunikasi terjalin dengan baik. Pembelajaran kontekstual terintegrasi AlQuran akan membuat siswa lebih aktif dalam proses pembelajaran, karena siswa dapat bertanya walaupun tidak dengan guru secara langsung. Kemudian, siswa juga dituntut untuk dapat mengemukakan pendapatnya. Dengan demikian, siswa tidak mungkin malu untuk bertanya dan mengemukakan pendapatnya karena mereka memiliki kebebasan untuk berpendapat sesuai dengan pemikirannya, namun tetap pada jalur materi yang dipelajari.

Pendekatan kontekstual terintegrasi Al-Quran mengedepankan keaktifan siswa dengan menghadirkan dunia nyata ke dalam kelas dan mengintegrasikan ayat AlQuran pada setiap materi (Siti Nurmiati, 2020). Pendekatan kontekstual terintegrasi Al-Quran merupakan suatu pendekatan yang menekankan pada proses keterlibatan siswa secara penuh untuk dapat menemukan materi dengan mengintegrasikan ayat 
Al-Quran yang dipelajari dan menghubungkannya dengan situasi dunia nyata sehingga menciptakan rasa syukur kepada Allah SWT atas segala kebesarannya dalam menjadikan proses yang kompleks dalam penciptaan manusia (Rusmono, 2014).

Pada tahap proses pembelajaran dengan CTL terintegrasi Al-Quran guru mempersiapkan lembar kerja siswa. Lembar kerja siswa itu digunakan untuk berdiskusi. Dengan adanya hal-hal baru yang ditampilkan secara nyata siswa akan lebih fokus untuk memperoleh ilmu pengetahuan yang mereka belum kuasai (Elaine B Johnson, 2018). Untuk pendahuluan, guru menjelaskan kompetensi yang harus dicapai serta manfaat dari proses pembelajaran dan pentingnya materi pelajaran yang akan dipelajari. Guru menjelaskan sedikit materi pelajaran yang akan dipelajari pada pertemuan itu dengan mengintegrasikan materi dengan ayat-ayat Al-Quran. Selanjutnya, guru memberikan pertanyaan yang terkait dengan materi yang dipelajari dengan mengintegrasikan materi tersebut kedalam ayat-ayat Al-Quran diantaranya yaitu:

1. Mengapa anak laki-laki harus dikhitan?

untuk menjaga agar di sana tidak terkumpul kotoran, juga agar leluasa untuk kencing, dan supaya tidak mengurangi kenikmatan dalam bersenggama. Jika kulit pada kemaluan yang akan dikhitan tersebut dibiarkan, kencing yang keluar dari lubang ujung kemaluan akan ada yang tersisa dan berkumpul pada tempat tersebut (Islamiyatur, Rokhmah ,2017). Hal ini dapat menyebabkan rasa sakit/pedih tatkala bergerak dan jika dipencet/ditekan sedikit akan menyebabkan kencing tersebut keluar sehingga pakaian dapat menjadi najis.

Sebagaimana hadits dari Abu Hurairah radhiyallahu 'anhu, Rasulullah shallallahu 'alaihi wa sallam bersabda:

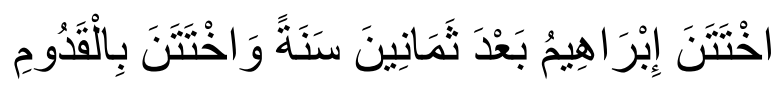

"Ibrahim berkhitan setelah mencapai usia 80 tahun, dan beliau berkhitan dengan Al Qodum." (HR. Bukhari, inilah lafadz yang terdapat dalam Shahih Bukhari yang berbeda dalam kitab Fiqh Sunnah).

2. Apakah donor ASI di bolehkan dalam syariat islam?

Salah satu bukti bahwa donor ASI diperbolehkan dalam Islam, menurut Isnawati pula, adalah pengalaman yang dialami oleh Nabi Muhammad SAW di masa kecilnya. Di mana saat itu beliau mempunyai ibu susu bernama Halimah. Kemudian Nabi Muhammad dibawa ke tempat tinggal Halimah di daerah pegunungan, karena saat itu keadaan Mekkah, khususnya kondisi udaranya, tidak lagi ideal bagi kelangsungan hidup bayi.

Ada dua jenis donor ASI, yaitu langsung dan tidak langsung. Donor langsung artinya sang ibu pendonor susu diketahui jelas identitasnya. Sementara dalam donor tidak langsung, identitas sang ibu pendonor bisa jelas, bisa juga tidak, dan mereka memberikan ASI melalui alat seperti selang atau dot.

Ada beberapa hal yang harus digaris bawahi oleh para ibu yang akan melakukan donor ASI, maupun mencari jasa donor ASI. Yaitu ternyata, ada 
dampak hukum terhadap donor ASI yang melarang atau mengharamkan hubungan pernikahan antara kedua keluarga yang memberikan donor ASI maupun yang menerimanya. Ketentuan itu dinamakan Mahram.

Adapun pengelompokan orang yang diharamkan untuk dinikahi karena sepersusuan yaitu perempuan yang menyusui dan ibunya, anak perempuan dari perempuan yang menyusui, saudara perempuan dari perempuan yang menyusui, anak perempuan dari anak perempuan dari perempuan yang menyusui, ibu dari suami dari perempuan yang menyusui, saudara perempuan dari suami dari perempuan yang menyusui, anak perempuan dari anak laki-laki dari perempuan yang menyusui, anak perempuan dari suami dari wanita yang menyusui, serta istri lain dari suami dari wanita yang menyusui.

Dituturkan pula, banyak pendapat yang telah dilontarkan mengenai Mahram ini. Ada beberapa ulama mengatakan, Mahram sudah terjadi saat penyusuan pertama kalinya. Sementara ulama lain menyebutkan, Mahram baru terjadi setelah 3 kali penyusuan.

Namun sebagian besar ulama menyepakati, kondisi Mahram baru terjadi setelah 5 kali penyusuan yang sempurna dalam waktu dua tahun. Artinya, jika seorang bayi meminum susu dari ibu pendonor yang sama lebih dari lima kali, dan setiap kali meminum ASI bayi itu merasa kenyang atau melepaskan sendiri mulutnya dari puting susu sang ibu, maka terjadi pengharaman hubungan pernikahan di antara kedua keluarganya.

"Jadi, ketika seorang bayi telah 5 kali berturut-turut menerima donor ASI dari ibu yang sama, maka terjadilah hubungan Mahram. Hal ini berlaku pada kedua jenis donor, langsung maupun tidak langsung

3. Apakah mengkonsumsi buah nanas dan nangka dapat menyebabkan keguguran?

Tidak ada jenis buah-buahan yang dilarang di dalam kehamilan. Mitos mengatakan bahwa nanas dan nangka dapat berbahaya dalam kehamilan. Namun sampai saat ini belum ada penelitian yang dapat membuktikannya (Neil A. Campbell, 2010). Nanas memang mengandung bromelaine yang apabila dikonsumsi dalam jumlah besar, bromelaine dapat meningkatkan kontraksi dinding rahim dan menyebabkan keguguran, terutama pada 3 bulan pertama kehamilan. Nanas juga sangat asam, teruatama pada wanita hamil terkadang dapat semakin memicu asam lambung sehingga dapat muncul mual atau muntah. Pada dasarnya, konsumsi buah jenis apapun tidak ada larangannya dalam kehamilan asalkan tidak berlebihan dan sesuai kebutuhan. sebagaimana firman Allah SWT dalam surat Al-A'raf ayat 31 yang berbunyi:

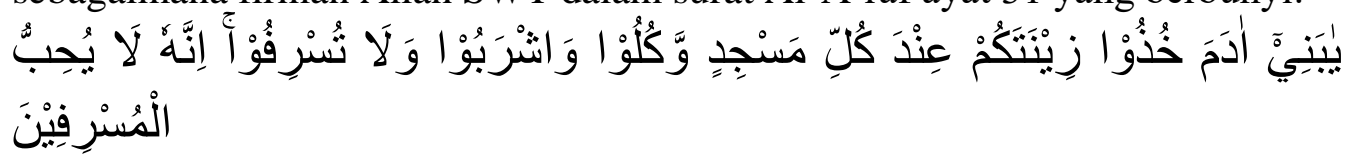


“Wahai anak cucu Adam! Pakailah pakaianmu yang bagus pada setiap (memasuki) masjid, makan dan minumlah, tetapi jangan berlebihan. Sungguh, Allah tidak menyukai orang-orang yang berlebihan."

Menurut tafsir Al-Qur'an Al Karim Hidayatul Insan, yang dimaksud dengan makan dan minum berlebihan adalah melebihi apa yang dibutuhkan, sehingga efeknya bisa membahayakan tubuh seseorang.

4. Apakah masturbasi atau onani hanya dilakukan pria dan menyebabkan dengkul kopong?

Masturbasi bisa dilakukan baik perempuan ataupun laki-laki. Dan perilaku ini bisa menyebabkan luka, keletihan dan kelelahan jika berlebihan, merasa berdosa dan tidak konsentrasi, ketergantungan dan tidak merasa butuh pasangan.

Jika seseorang melakukan onani hanya untuk membangkitkan syahwat, hukum masturbasi dalam Islam adalah haram secara umum. Karena Allah Ta'ala berfirman dalam Al-Quran Al Ma'arij: 29-31.

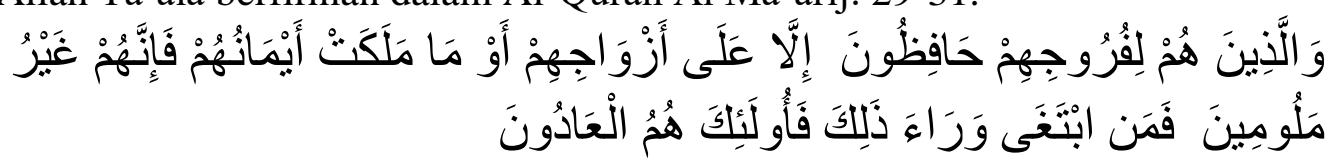

"Dan orang-orang yang memelihara kemaluannya, kecuali terhadap isteriisteri mereka atau budak-budak yang mereka miliki, maka sesungguhnya mereka dalam hal ini tiada tercela. Barangsiapa mencari yang di balik itu, maka mereka itulah orang-orang yang melampaui batas.” (QS. Al Ma'arij: 29-31).

Kemudian Guru memberikan LKS kepada siswa. Setelah diberi waktu beberapa menit, pada kegiatan inti siswa dikelompokkan sesuai dengan pasangan yang telah ditentukan. Siswa diberi waktu untuk mendiskusikan pemikirannya tentang pertanyaan yang diberikan tadi atau materi yang akan dibahas. Langkah selanjutnya, siswa mempresentasikan hasil diskusi kepada seluruh kelas. Ketika ada pasangan yang mempresentasikan hasil diskusi, siswa yang lain diberi kesempatan untuk bertanya maupun mengungkapkan pendapatnya kepada pasangan yang sedang presentasi didepan. Dengan demikian, siswa akan menjadi lebih aktif dan kreatif dalam proses pembelajaran. Proses penutupnya adalah dengan bantuan arahan dari guru, siswa menyimpulkan hasil diskusi yang telah dilakukan (Trianto, 2015)

Setelah mendapat pembelajaran dengan menggunakan model pembelajaran contextual teaching learning, nilai posttest prestasi belajar kelas eksperimen mengalami peningkatan yang cukup signifikan, sedangkan siswa kelas kontrol yang tidak menggunakan model pembelajaran contextual teaching learning mengalami peningkatan yang lebih kecil. Diketahui nilai rata-rata pretest kelas kontrol sebesar 52,3 dan skor rata-rata posttets kelas kontrol sebesar 74,6 yang berarti terjadi peningkatan prestasi belajar sebesar 22. Sedangkan pada kelompok eksprimen diketahui skor rata-rata pretest sebesar 54,3 dan skor rata-rata posttest sebesar 85,4. Dari hasil tersebut, kelompok eksperimen mengalami kenaikan sebesar 31,2. Hal ini menunjukkan bahwa prestasi belajar kelas eksperimen mengalami kenaikan yang 
lebih besar dari pada siswa kelas kontrol. Berikut rangkuman nilai rata-rata pretest dan posttest.

Tabel 2. Rangkuman nilai rata-rata pretest dan posttest

\begin{tabular}{cccccccc}
\hline No. & Kelompok & $\begin{array}{c}\text { Nilai } \\
\text { Rata- } \\
\text { Rata }\end{array}$ & $\begin{array}{c}\text { Nilai } \\
\text { Rata } \\
\text { Rata } \\
\text { Pretest }\end{array}$ & $\begin{array}{c}\text { standar } \\
\text { Peviasi } \\
\text { Pretest }\end{array}$ & $\begin{array}{c}\text { standar } \\
\text { Deviasi } \\
\text { Posttest }\end{array}$ & Selisih & Persentase \\
\hline 1. & $\begin{array}{c}\text { Kelompok } \\
\text { Eksperimen }\end{array}$ & 54,3 & 85,4 & 6,22 & 3,48 & 31 & $84,4 \%$ \\
\hline 2. & $\begin{array}{c}\text { Kelompok } \\
\text { Kontrol }\end{array}$ & 52,3 & 74,6 & 5,62 & 3,24 & 22 & $73,6 \%$ \\
\hline
\end{tabular}

Berdasarkan Tabel diatas dapat disimpulkan bahwa pembelajaran menggunakan model pembelajaran $C T L$ terintegrasi Al-Quran dapat meningkatkan hasil beajar siswa pada materi sistem reproduksi manusia. Dibandingkan dengan kelas kontrol yang tidak menggunakan model pembelajaran $C T L$ terintegrasi Al-Quran hasil prestasi belajarnya lebih rendah. Selisih persentase kenaikan dari pretest ke posttest juga lebih besar kelas ekperimen dengan $84,4 \%$ dari pada kelas kontrol dengan 73,6\%. Untuk mengetahui sumbangan efektif penggunaan model pembelajaran contextual teaching learning terhadap peningkatan hasil belajar siswa pada materi sistem reproduksi manusia dapat digunakan rumus (Sandu Siyoto, 2015).

$(S P E-S P K=S E)$

Dimana:

SPE : Selisih Persentase Eksperimen

SPK : Selisih Persentase Kontrol

SE : Sumbangan Efektif

Dari rumus tersebut dapat diperoleh sumbangan efektif dari penggunaan model pembelajaran $C T L$ terintegrasi Al-Quran adalah $85,4 \%-73,6 \%=11,8 \%$. Dari nilai ratarata posttest tesebut juga dapat dihitung efisiensi relatif dengan rumus $=P=$ $\frac{\bar{X} \text { pretest eksperimen }}{\overline{\text { Xposttest eksperimen }}} \times 100 \%$, sehingga dapat diperoleh sumbangan relatif dari penggunaan model pembelajaran contextual teaching learning adalah $\frac{54,3}{85,4} \times 100 \%=$ $63,23 \%$.

Model pembelajaran $C T L$ terintegrasi Al-Quran terbukti memberikan perbedaan hasil belajar antara kelas eksperimen dengan kelas kontrol. Perbedaan hasil belajar yang terjadi tersebut merupakan akibat dari proses pengontrolan dan perlakuan pada masingmasing kelas. model CTL terintegrasi Al-Quran dapat membuat hasil belajar lebih baik karena dapat terjadi interaksi banyak arah dalam proses belajar siswa di kelas (Arimadona Siska, 2016). Me numbuhkan nuasa islami dalam pembelajaran biologi pada materi sistem reproduksi manusia, sehingga menjadikan siswa lebih dekat kepada Allah SWT dengan menjadikan Al-Quran sebagai acuan dalam pembelajaran biologi khususnya pada materi sistem reproduksi manusia. Selain itu Keaktifan siswa tersebut 
yang memberikan pengaruh yang lebih nyata terhadap hasil belajar yang diperoleh. Pembelajaran yang diterapkan lebih mengembangkan sistem diskusi antara siswa, sehingga secara langsung mampu mengembangkan kerja sama antara siswa.

\section{Kesimpulan}

Berdasarkan tujuan penelitian dapat disimpulkan bahwa, terdapat efektivitas pendekatan konstektual terintegrasi di Al-Quran terhadap hasil belajar biologi kelas XI pada materi sistem reproduksi manusia, yang mana dibuktikan dari hasil pretest dan posttest pada kelas kontrol yang terdapat peningkatan sebesar 73,6\% sedangkan pada kelas eksperimen terdapat peningkatan sebesar 84,4\%. Uji $\mathrm{N}$-Gain juga menunjukkan pada kelas eksperimen sebesar 0,87 (kategori tinggi) dan pada kelas kontrol sebesar 0,58 (kategori sedang) dan terdapat pencapaian kompetensi hasil belajar yang dapat dibuktikan dengan $\mathrm{H}_{0}$ di tolak dan $\mathrm{H}_{\mathrm{a}}$ karena rata- rata hasil belajar materi sistem reproduksi manusia menggunakan pendekatan konstektual terintegrasi Al-Quran lebih tinggi dari pada hasil belajar menggunakan pendekatan ceramah. 
Efektivitas Pendekatan Konstektual Terintegrasi Al-Quran Terhadap Hasil Belajar

Siswa

\section{BIBLOGRAFI}

Al-maragi, Ahmad Musthafa. (2006). Tafsir al-Maragi, Jilid 6. Bairut: Dar al-Fikri. Google Scholar

Islamiyatur, Rokhmah. (2017). Kesehatan Reproduksi dalam Perspektif Al-Qur'an (Kajian Ayat-ayat Kebidanan), Jurnal kebidanan dan keperawatan. 13 (2), 141149. Google Scholar

Johnson, Elaine B. (2018). Contextual teaching and learning. Bandung: Kaifa. Google Scholar

Jumanta, Hamdayama. (2014). Model dan Metode Pembelajaran Kreatif dan Berkarakter. Bogor: Ghalia Indonesia. Google Scholar

Neil A. Campbell dkk. (2010). Biologi Edisi 8 Jilid 3. Jakarta: Erlangga. Google Scholar

Nurhayati, Abbas 2017, Penerapan Model Pembelajaran Berdasarkan Masalah (Problembased Instruction) Dalam Pembelajaran Matemalika di SMU, Jurnal Pendidikan dan kebudayaan, 7 (23), h, 86-98 Google Scholar

Nurmiati, Siti. (2020). Pengembangan Bahan Ajar Biologi Berbasis Karakter Menurut Al-Qur'an pada Materi Sistem Reproduksi di SMA Kelas XI IPA. 6 (1), 17-28. Google Scholar

Purwanto. (2018). Teknik Penyusuna Instrumen (Uji Validitas dan Reliabilitas untuk Penelitian Ekonomi Syariah). Magelang: StaiaPress. Google Scholar

Riyana, Sepi. (2015). Kurikulum pembelajaran. Bandung: UPI. Google Scholar

Rusmono. (2014). Strategi pembelajaran constektual teaching and learning. Bogor: Ghalia Indonesia. Google Scholar

Sholeh. (2016). Pendidikan dalam Al-Quran (konsp ta'lim surat Al- Mujadalah ayat 11). Jurnal At-thariqoh. 1 (2), 207-208 Google Scholar

Siska, Arimadona. (2016). Pengembangan Modul Pembelajaran Biologi Berbasis Integrasi Islam Sains. 1 (2), 89-98. Google Scholar

Siyoto, Sandu. (2015). Dasar Metodologi Penelitian. Yogyakarta: KDT. Google Scholar

Trianto. (2015). Model Mod Model-model Pembelajaran inovatif Berorientasi Konstruktivistik: Konsep, Landasan Teoritis-Praktis dan Implementasinya. Jakarta: Prestasi Pustaka Publisher. Google Scholar

First publication right:

Jurnal Syntax Fusion: Jurnal Nasional Indonesia

This article is licensed under:

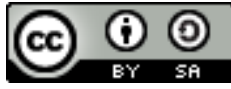

